УДК 340.1

DOI 10.18413/2712-746X-2020-44-2-330-335

\title{
Цели льготных правовых режимов
}

\author{
Подольский А.В. \\ Тамбовский государственный технический университет \\ 392000 г. Тамбов, ул. Советская, 106. \\ E-mail: mse.shurik@gmail.com
}

\begin{abstract}
Аннотация. Изучение льготных правовых режимов как разновидности специальных правовых режимов следует начинать с определения целей их установления. Понятие «льготный правовой режим» мало исследовано и подвергалось анализу только в работах, посвященных правому режиму в целом. Главным функциональным назначением льготных правовых режимов является облегчение правового положения субъектов. На основании этого автором определены цели установления льготных правовых режимов. Обоснована точка зрения, что поскольку они создают условия интенсификации осуществления субъектам права своих прав, одной из целей льготных правовых режимов является реализация принципа социальной справедливости. В качестве другой их цели, которая также достигается через облегчение правового положения, видится стимулирование значимой для общества и государства позитивной активности. В подтверждение данной точки зрения приведены примеры льготных правовых режимов, в рамках которых достигаются обозначенные цели. Результаты исследования открывают новое теоретическое направление в исследовании проблем льготных правовых режимов и их отраслевого использования.
\end{abstract}

Ключевые слова: льгота, социальная справедливость, правовое равенство, позитивная активность, правовой стимул.

Для цитирования: Подольский А.В. 2020. Цели льготных правовых режимов NOMOTHETIKA: Философия. Социология. Право. 45 (2): 330-335. DOI 10.18413/2712-746X-2020-44-2-330-335

\section{Goals of preferential legal regimes}

\author{
Alexander V. Podolsky \\ Tambov State Technical University \\ 106 Sovetskaya str., Tambov, 392000, Russia \\ E-mail: mse.shurik@gmail.com
}

\begin{abstract}
The study of preferential legal regimes as a type of special legal regimes should begin with defining the goals of their establishment. The concept of "preferential legal regime" has not been well studied and has been analyzed only in works devoted to the legal regime as a whole. The main functional purpose of preferential legal regimes is to facilitate the legal status of subjects. Based on this, the author defines the goals of establishing preferential legal regimes. The point of view is substantiated that since they create conditions for the intensification of the exercise of rights by legal subjects, one of the goals of preferential legal regimes is the implementation of the principle of social justice. Their other goal, which is also achieved by facilitation the legal situation, is to encourage positive activity that is significant for society and the state. In support of this point of view, examples of preferential legal regimes are given in which the designated goals are achieved. The results of the research open a new theoretical direction in the study of problems of preferential legal regimes and their use in the branches of law.
\end{abstract}

Keywords: benefits, social justice, legal equality, positive activity, legal incentive.

For citation: Podolsky A.V. 2020. Goals of preferential legal regimes. NOMOTHETIKA: Philosophy. Sociology. Law series. 45 (2): 330-335 (in Russian). DOI 10.18413/2712-746X-2020-44-2-330-335 


\section{Введение}

В современных условиях льготные правовые режимы занимают особое место среди инструментов социальной политики государства. Стремясь к построению общества равных возможностей, государство создает особые льготные порядки реализации прав и исполнения обязанностей для отдельных индивидов или групп лиц.

В научной литературе вопросы целей и сущности правовых режимов вообще и специальных режимов, в частности подвергались исследованию в работах А.В. Малько [Малько, Лиманская, 2014], Г.С. Беляевой [Беляева, 2013], А.П. Лиманской [Лиманская, 2014], Н.С. Братановского [Братановский, 2012], и других. Однако цели льготных правовых режимов отдельно не исследовались.

\section{Правовое равенство и социальная справедливость}

В современных условиях льготные правовые режимы занимают особое место среди инструментов социальной политики государства. Стремясь к построению общества равных возможностей, государство создает особые льготные порядки реализации прав и исполнения обязанностей для отдельных индивидов или групп лиц.

В ст. 7 Конституции Российская Федерация провозглашается социальным государством, политика которого направлена на создание условий, обеспечивающих достойную жизнь и свободное развитие человека. А в соответствии с п. 1 ст. 19 Конституции все равны перед законом и судом. Правовое равенство выступает в качестве одного из важнейших принципов правового регулирования, как существенная ценность, оберегаемая законом.

Однако равные права, декларируемые основным законом государства, в процессе их осуществления (в динамике) могут перестать быть равными. Существуют определенные объективные уважительные причины, когда субъект не имеет возможности осуществить предоставленное ему право тем способом (при помощи тех правовых средств), которые предлагает ему закон. Препятствием могут выступать как субъективные причины (инвалидность, возраст, пол и пр.), так и объективные (суровые природные условия, социальная напряженность, геополитическая обстановка и т.д.). В этом случае должны использоваться альтернативные правовые средства осуществления и защиты прав и законных интересов. С помощью таких средств должны создаваться льготные правовые режимы, позволяющие субъектам, ограниченным в своих возможностях, осуществить субъективное право.

Одной из целей льготного правого режима выступает социально значимый результат, выражающийся в установлении правового равенства и социальной справедливости. Данные правовые режимы могут быть предусмотрены для особого урегулирования различных сфер общественной жизни. Они во множестве содержатся в жилищном, налоговом, пенсионном законодательстве, законодательстве о труде, образовании и т.д.

Так, Трудовой кодекс Российской Федерации [2001] предусматривает целый ряд льготных правовых режимов, призванных уравнять в правах и социальных гарантиях разные категории работников. К примеру, ежегодный оплачиваемый отпуск предоставляется в удобное для работника время следующим категориям граждан: лицам, воспитывающим детей-инвалидов в возрасте до 18 лет (ст. 262.1); лицам, имеющим трех и более детей до 18 лет (ст. 261.2); лицам, не достигшим 18 лет (ст. 267); и пр. Особый льготный правовой режим предусмотрен главой 50 Трудового кодекса РФ в отношении лиц, работающих в районах Крайнего Севера и приравненных к ним местностях. В частности, ст. 315 предусматривает особый порядок оплаты труда таких работников в виде специальных увеличивающих коэффициентов и надбавок; ст. 321 устанавливает дополнительные ежегодные оплачиваемые отпуска продолжительностью 24 календарных дня работников районов Крайнего Севера и 16 календарных дней для лиц, работающих в местностях, приравненных к ним и т.д. 
Очевидно, что указанные категории работников уже ограничены в своих возможностях осуществления трудовых прав (в том числе права на отдых) в силу возраста, тяжелых климатических условий жизни и деятельности, физиологических, семейных и иных трудностей. Установление для них льготных режимов трудовой деятельности и дополнительных денежных гарантий преследует цель облегчить их правовое положение и, тем самым, уравнять их права с правами остальных работников.

В сфере образования льготные режимы в основном касаются вопросов поступления в учебные заведения и прохождения обучения. Они обеспечивают равный доступ к образованию путем предоставления определенных преимуществ для социально уязвимых категорий граждан. Так, например, п. 5. ст. 71 Федерального закона «Об образовании в Российской Федерации» от 29.12.2012 № 273-Ф3 [2012] устанавливает право на прием на обучение в пределах установленной специальной квоты (вне общего конкурса) за счет бюджетных ассигнований соответствующего бюджета детей-инвалидов, инвалидов I и II групп, инвалидов детства, инвалидов вследствие военной травмы или заболевания, полученных в период прохождения военной службы.

Особое место среди льготных правовых режимов занимают правовые режимы, обеспечивающие социальную поддержку семей. Их особенностью является двоякая направленность: во-первых, снижение материальной нагрузки на растущую семью, а во-вторых, стимулирование рождаемости и тем самым преодоление демографического кризиса.

Семья - один из главных социальных институтов в обществе, на котором зиждется государство. Именно поэтому государство уделяет пристальное внимание многодетным семьям, ведь зачастую в таких семьях имеет возможность работать только один из родителей. Указ Президента РФ «О мерах по социальной поддержке многодетных семей» от 05.05.1992 № 431 (ред. от 25.02.2003) [1992] более четверти века не теряет своей актуальности и значимости. Согласно указу, многодетным семьям предоставляется целый ряд льгот (в частности скидка в размере не ниже 30 процентов установленной платы за пользование отоплением, водой, канализацией, газом и электроэнергией; бесплатная выдача лекарств, приобретаемых по рецептам врачей, для детей в возрасте до 6 лет и пр.).

Во многих регионах действуют специальные программы по субсидированию покупки жилья и улучшению жилищных условий для многодетных семей. Так, постановлением Правительства Московской области от 25.10.2016 № 790/39 (ред. от 26.03.2019) «Об утверждении государственной программы Московской области «Жилище» на 20172027 годы» [2016] установлены «Правила предоставления жилищных субсидий многодетным семьям на приобретение жилого помещения или строительство индивидуального жилого дома», согласно которым многодетным семьям, имеющим семь и более детей, выдается жилищная субсидия на приобретение жилья.

Из приведенных выше примеров видно, что льготные правовые режимы устанавливаются с целью обеспечения равенства и социальной справедливости. Предусмотренные в тех или иных правовых режимах льготы адресно воздействуют на тех субъектов, которые не могут в силу объективных причин наравне с другими осуществлять свои права и реализовывать законные интересы. Льготный правовой режим в этих случаях выполняет компенсационную функцию, являясь инструментом восстановления правового равенства. Данная функция является необходимым инструментом гармонизации интересов субъектов права, стабильности общественных отношений.

\section{Стимулирование социальной и экономической активности субъектов}

Однако, помимо инструмента установления равенства и социальной справедливости, льготные правовые режимы используются и как средство достижения положительного социального и экономического эффекта, отвечая тем самым цели правового стимулирования - 
удовлетворение потребности общества и государства в социально полезном и активном поведении субъектов права в различных сферах жизнедеятельности [Малько, 2004, с. 84].

Такого рода льготные правовые режимы устанавливаются, к примеру, для облегчения правового положения субъектов предпринимательства. Существуют специальные льготные правовые режимы ведения хозяйственной деятельности, устанавливаемые либо на определенной территории (в определенной местности), либо на всей территории Российской Федерации.

Так, в соответствии со ст. 11 Федерального закона «О развитии сельского хозяйства» от 29.12.2006 № 264-Ф3 [Федеральный..., 2006] государством обеспечивается поддержка формирования и развития системы кредитования сельскохозяйственных товаропроизводителей.

Для стимулирования инвестирования в российскую экономику и вывода из офшорных зон на территории Российской Федерации создаются специальные административноправовые режимы, основанные на льготах и преимуществах. Это режимы, связанные с решением актуальных социально-экономических проблем: режим территории опережающего развития; режим территорий, созданных для внедрения инноваций; режим приграничного сотрудничества и свободного порта; режим промышленного кластера и пр. [Ноздрачев, Стародубова, 2016, с. 147].

К примеру, привлекательные налоговые преференции предлагает резидентам режим территории опережающего социально-экономического развития. Для организаций, получивших статус резидента территории опережающего социально-экономического развития, налоговая ставка по налогу, подлежащему зачислению в федеральный бюджет, устанавливается в размере $0 \%$. [Налоговый..., 2000].

Положительный экономический эффект достигается также в рамках правовых режимов освобождения от определенного рода ответственности, связанной с экономической деятельностью субъекта. Указанные льготные правовые режимы направлены на возвращение правонарушителя в рамки правового поля.

Особую актуальность в этой сфере приобрел режим так называемой амнистии капиталов. В рамках Федерального закона «О добровольном декларировании физическими лицами активов и счетов (вкладов) в банках и о внесении изменений в отдельные законодательные акты Российской Федерации» от 08.06.2015 № 140-Ф3 [2015] устанавливается режим освобождения от уголовной ответственности за преступления, связанные с уклонением от обязанности по репатриации денежных средств, уклонением от уплаты таможенных платежей в крупном и особо крупном размере, уклонением от уплаты налоговых сборов и т.д.; административной ответственности за осуществление предпринимательской деятельности без государственной регистрации в качестве индивидуального предпринимателя или без государственной регистрации в качестве юридического лица; ответственности за некоторые налоговые правонарушения.

\section{Заключение}

Таким образом, из вышеизложенного следует, что у льготных правовых режимов определяются два направления их воздействия на общественные отношения и, соответственно, две основные цели: 1) создание условий для установления равноправия и понижения уровня сочиального неравенства; 2) стимулирование субъектов, в правомерной деятельности и активности которых экономически и социально заинтересовано государство.

Исходя из поставленных целей все льготные правовые режимы, главным образом, делятся на две категории: режимы, устанавливающие равноправие и социальную справедливость, и режимы, стимулирующие значимую для государства позитивную активность субъектов (условно назовем первые социальными, а вторые социально-экономическими). При этом существуют льготные правовые режимы, относящиеся только к первой катего- 
рии (например, режим особого права на поступление в высшие учебные заведения), либо только ко второй (например, режим хозяйственной деятельности на территории опережающего развития), а также режимы, в которых достигаются сразу две главные цели льготного правового регулирования (например, режим ведения крестьянского (фермерского) хозяйства многодетными семьями).

Определив две основные цели льготного правового регулирования, наиболее значимой из них все же представляется первая - обеспечение правового равенства и социальной справедливости. Во-первых, потому что Российская Федерация является, согласно ст. 7 Конституции, социальным государством. Данное положение Конституции РФ реализуется при помощи различных правовых инструментов, в том числе посредством льготных правовых режимов. Осуществляя политику, направленную на создание условий по обеспечению достойной жизни и свободного развития человека, государство через льготные правовые режимы выравнивает возможности различных категорий субъектов права. Предусмотренные в льготных правовых режимах юридические средства адресно воздействуют на тех субъектов, которые не могут в силу объективных причин наравне с другими осуществлять свои права и реализовывать законные интересы. А во-вторых, потому что вторая цель льготного правового регулирования, хотя и оказывает решающее значение на развитие экономики и других сфер общественной жизни и деятельности, имеет шанс быть достигнутой только в условиях правого и социального равенства и общего благополучия граждан. Ведь вовлекать людей в полезные сферы деятельности, стимулировать их к позитивной активности и развитию можно только в условиях стабильности и защищенности, в условиях равных возможностей реализации прав и законных интересов.

\section{Список источников}

1. Налоговый кодекс Российской Федерации (часть вторая) от 05.08.2000 № 117-Ф3 (ред. от 17.06.2019) // Собрание законодательства РФ. 2000 № 32. Ст. 3340.

2. Постановление Правительства Московской области от 25.10.2016 № 790/39 (ред. от 26.03.2019) «Об утверждении государственной программы Московской области «Жилище» на 20172027 годы». URL: https://mosreg.ru/dokumenty/normotvorchestvo/prinyato-pravitelstvom/29-11-2016-1641-09-postanovlenie-pravitelstva-moskovskoy-oblasti-ot-2. (дата обращения: 25 сентября 2019).

3. Трудовой кодекс Российской Федерации от 30.12.2001 № 197-Ф3 // Собрание законодательства РФ.2002. № 1 (ч. 1), ст. 3.

4. Указ Президента РФ «О мерах по социальной поддержке многодетных семей» от 05.05.1992 № 431 (ред. от 25.02.2003) // Ведомости СНД и ВС РФ. 1992. № 19. Ст. 1044.

5. Федеральный закон «О добровольном декларировании физическими лицами активов и счетов (вкладов) в банках и о внесении изменений в отдельные законодательные акты Российской Федерации» от 08.06.2015 № 140-Ф3 // Собрание законодательства РФ. 2015. № 24. Ст. 3367.

6. Федеральный закон «О развитии сельского хозяйства» от 29.12.2006. № 264-Ф3 // Собрание законодательства РФ. 2007. № 1 (1 ч.). Ст. 27.

7. Федеральный закон «О территориях опережающего социально-экономического развития в Российской Федерации» от 29.12.2014 № 473-Ф3 // Собрание законодательства РФ. 2015, № 1 (часть I). Ст. 26.

8. Федеральный закон «Об образовании в Российской Федерации» от 29.12.2012 № 273-Ф3 // Собрание законодательства РФ. 2012. № 53 (ч. 1). Ст. 7598.

\section{Список литературы}

1. Александров Ю.В. 2003. Справедливость как базовая ценность российской правовой культуры. Правоведение: межвузовский научно-методический сборник. Великий Новгород, 4: 18-22.

2. Беляева Г.С. 2013. К вопросу о сущности правового режима. Гражданин и право, 2: 8-13.

3. Братановский С. Н. 2012. Сущность и виды специальных правовых режимов информации. Гражданин и право, 9: 3-17. 
4. Искевич И.С., Куркин Б.А. 2019. К вопросу о правовых режимах внешнеторговой деятельности. Международное публичное и частное право, 3: 29-33.

5. Лапаева В.В. 2007. Формальное равенство как критерий правового начала в общественной жизни. Труды института государства и права РАН, 4: 87-106.

6. Лиманская А.П. 2014. Цели специальных правовых режимов. Законы России: опыт, анализ, практика, 2: 95-97.

7. Малько А.В. 2004. Стимулы и ограничения в праве. М., Юристь, 248 с.

8. Малько А.В., Лиманская А.П. 2014. Виды правовых режимов в юридической науке и российском законодательстве. Современное право, 2: 14-17.

9. Морозова И.С. 2007. Теория правовых льгот: дис. ...доктора юрид. наук. Саратов, 427 с.

10. Ноздрачева А.Ф., Стародубова О.Е. 2016. Административно-правовые режимы: современное содержание и тенденции развития. Журнал российского права, 9: 146-153.

\section{References}

1. Aleksandrov Yu. V. 2003. Justice as a basic value of Russian legal culture [Justice as a basic value of Russian legal culture]. Jurisprudence: Intercollegiate scientific and methodological collection [Jurisprudence: interuniversity scientific and methodical collection]. Velikiy Novgorod, 4: 18-22.

2. Belyaeva G. S. 2013. To the question of the essence of the legal regime [To the question of the essence of the legal regime]. Grazhdanin i pravo, 2: 8-13

3. Bratanovskiy S. N. 2012. The nature and types of special legal regimes of information [The nature and types of special legal regimes of information]. Grazhdanin i pravo, 9: 3-17.

4. Iskevich I. S., Kurkin B. A. 2019. On legal regimes of foreign trade activities [On legal regimes of foreign trade activities] Mezhdunarodnoe publichnoe i chastnoe pravo, 3: 29-33.

5. Lapaeva V. V. 2007. Formal equality as a criterion of legal principle in public life [Formal equality as a criterion of legal principle in public life]. Proceedings of the institute of State and law of RAS, 4: 87-107.

6. Limanskaya A. P. 2014. The purpose of the special legal regimes. [The purpose of the special legal regimes]. Zakony Rossii: opyt, analiz, praktika, 2: 95-97.

7. Mal'ko A.V. 2004. Incentives and restrictions in law [Incentives and restrictions in law]. M., Yurist, $248 \mathrm{p}$.

8. Mal'ko A.V. Limanskaya A. P. Types of legal regimes in legal science and Russian legislation. [Types of legal regimes in legal science and Russian legislation]. Sovremennoe pravo, 2: 14-17.

9. Morozova I.S. 2004. Theory of legal benefits [Theory of legal benefits] dis. ...doct. law . sciences. Saratov, 2007, $427 \mathrm{p}$.

10. Nozdracheva A.F., Starodubova O.E. 2016. Administrative and legal regimes: current content and development trends [Administrative and legal regimes: current content and development trends]. Zhurnal rossiiskogo prava, 9: 146-153.

\section{ИНФОРМАЦИЯ ОБ АВТОРЕ}

Подольский Александр Владимирович, старший преподаватель кафедры «Международное право» ФГБОУ ВО «ТГТУ», г. Тамбов, Россия

\section{INFORMATION ABOUT THE AUTHOR}

Aleksandr V. Podolskiy, senior lecturer of the Department of International law, Federal state budget educational institution of higher education «Tambov state technical University», Tambov, Russia. 